\title{
Molecular identification of naturally occurring bacteriocinogenic and bacteriocinogenic-like lactic acid bacteria in raw milk and soft cheese
}

\author{
M. B. T. Ortolani, ${ }^{*}$ P. M. Moraes, ${ }^{*}$ L. M. Perin, ${ }^{*}$ G. N. Viçosa, ${ }^{*}$ K. G. Carvalho, † A. Silva Júnior, ${ }^{*}$ and L. A. Nero* \\ *Departamento de Veterinária, Universidade Federal de Viçosa, Viçosa, MG, Brazil, 36570-000 \\ †Faculdade de Ciências Farmacêuticas, Universidade de São Paulo, São Paulo, SP, Brazil, 05508-900
}

\begin{abstract}
Lactic acid bacteria (LAB) are currently used by food industries because of their ability to produce metabolites with antimicrobial activity against gram-positive pathogens and spoilage microorganisms. The objectives of this study were to identify naturally occurring bacteriocinogenic or bacteriocinogenic-like LAB in raw milk and soft cheese and to detect the presence of nisincoding genes in cultures identified as Lactococcus lactis. Lactic acid bacteria cultures were isolated from 389 raw milk and soft cheese samples and were later characterized for the production of antimicrobial substances against Listeria monocytogenes. Of these, 58 (14.9\%) LAB cultures were identified as antagonistic; the nature of this antagonistic activity was then characterized via enzymatic tests to confirm the proteinaceous nature of the antimicrobial substances. In addition, 20 of these antagonistic cultures were selected and submitted to genetic sequencing; they were identified as Lactobacillus plantarum $(\mathrm{n}=2)$ and Lactococcus lactis ssp. lactis $(\mathrm{n}=18)$. Nisin genes were identified by polymerase chain reaction in 7 of these cultures. The identified bacteriocinogenic and bacteriocinogenic-like cultures were highly variable concerning the production and activity of antimicrobial substances, even when they were genetically similar. The obtained results indicated the need for molecular and phenotypic methodologies to properly characterize bacteriocinogenic LAB, as well as the potential use of these cultures as tools to provide food safety.
\end{abstract}

Key words: lactic acid bacteria, antagonism, bacteriocin, nisin

\section{INTRODUCTION}

Lactic acid bacteria (LAB) have become very important in the food industry and in public health because of their antagonistic potential against pathogenic and spoilage microorganisms. Such activity is attributed

Received December 15, 2009

Accepted March 28, 2010.

${ }^{1}$ Corresponding author: nero@ufv.br to their growth that competes with other microorganisms in foods. Moreover, their activity is strengthened by the inhibitory effects of their metabolites, such as organic acids, hydrogen peroxide, $\mathrm{CO}_{2}$, diacetyl, and bacteriocins (Carr et al., 2002; de Martinis et al., 2003). Bacteriocins have been heavily studied because of their significance as biopreservatives (Carr, et al., 2002).

Bacteriocins are biologically active peptides or proteins that present antagonistic activity against specific microorganisms (Lewus and Montville, 1991; Thuault et al., 1991; Carr, et al., 2002). Bacteriocins are sensitive to protease activity because of their proteinaceous nature, which can be identified by specific inhibition tests (Harris et al., 1989; Lewus et al., 1991; Lewus and Montville, 1991; Hoover and Steenson, 1993). Several LAB species have been identified as producers of different bacteriocins (Chen and Hoover, 2003; Cotter et al., 2005).

The expression of bacteriocins is mediated by genes (Chen and Hoover, 2003), many of which have been sequenced (Maldonado et al., 2003; Todokoro et al., 2006). Genetic sequencing is a very important tool for the description of these genes and has been indispensable for the precise identification of new bacteriocinogenic LAB cultures (Holzapfel et al., 2001; Nes and Johnsborg, 2004; Mohania et al., 2008).

Although there is plenty of information on LAB activity in different kinds of foods (Lewus et al., 1991; Thuault et al., 1991; Issa and Ryser, 2000; de Martinis et al., 2003; de Martinis and Freitas, 2003), the identification of new bacteriocinogenic strains is necessary to provide novel tools for pathogen control. Therefore, the objective of this study was to detect LAB cultures naturally present in raw milk and soft cheese, with bacteriocinogenic or bacteriocinogenic-like activity, for future application in the food industry as biopreservatives.

\section{MATERIALS AND METHODS}

\section{Sample Collection and LAB Isolation}

Samples of raw milk $(\mathrm{n}=36)$ and soft cheese produced with raw milk $(\mathrm{n}=18)$ were collected under 
aseptic conditions from bulk tanks and dairy farms from Viçosa (Minas Gerais, Brazil. The samples remained refrigerated until they were carefully homogenized and submitted to 10-fold dilution using $0.85 \%$ $\mathrm{NaCl}$. The dairy farms were selected to represent the microbial profile of the milk produced in the region, according to the dairy production characteristics (Nero et al., 2009a). Sample dilutions were plated on de Man, Rogosa, Sharpe (MRS) agar (Oxoid Ltd., Basingstoke, UK) and incubated at $35^{\circ} \mathrm{C}$ for $48 \mathrm{~h}$ under anaerobiosis (Anaerobac, Probac do Brasil, São Paulo, SP, Brazil) for LAB isolation.

\section{Antagonistic Activity of Naturally Occurring LAB}

Bacterial Cultures. Reference cultures of Listeria monocytogenes ATCC 7644, Lactobacillus sakei 2a, and Lactococcus lactis ssp. lactis DY 13 (Lyofast Dry DY 13, Prime Pharma CC, Gordons Bay, South Africa) were maintained under refrigeration in tubes containing trypticase soy agar (Oxoid) or MRS (Oxoid). Before use, the cultures were grown in trypticase soy broth (Oxoid) or MRS (at $35^{\circ} \mathrm{C}$ for $24 \mathrm{~h}$ ) and diluted in trypticase soy broth or MRS broth until they achieved turbidity similar to tube no. 1 on the McFarland scale $\left(3 \times 10^{8} \mathrm{cfu} / \mathrm{mL}\right)$.

From the MRS plates, 389 colonies were randomly selected (around $10 \%$ of the observed count), purified in MRS agar (at $35^{\circ} \mathrm{C}$ for $24-48 \mathrm{~h}$ ), lyophilized, and stored at $-80^{\circ} \mathrm{C}$. For the antagonism test, the stored cultures were recovered in MRS broth (Oxoid) at $35^{\circ} \mathrm{C}$ for 24 $\mathrm{h}$; after confirmation of the purity in MRS agar (at $35^{\circ} \mathrm{C}$ for $24-48 \mathrm{~h}$ ), a single colony was inoculated into MRS broth (at $35^{\circ} \mathrm{C}$ for $24 \mathrm{~h}$ ). The obtained cultures were then diluted in MRS broth until they achieved turbidity similar to tube no. 1 on the McFarland scale $\left(3 \times 10^{8} \mathrm{cfu} / \mathrm{mL}\right)$.

Detection of the Antagonistic Activity. Culture aliquots of $2 \mu \mathrm{L}$ were inoculated onto plates containing $10 \mathrm{~mL}$ of brain heart infusion (BHI) agar (Oxoid) supplemented with a catalase solution (Sigma, St. Louis, MO) to a final concentration of $100 \mathrm{IU} / \mathrm{mL}$, and the cultures were incubated at $30^{\circ} \mathrm{C}$ for $24 \mathrm{~h}$. At this stage, the production of acids was minimized by the use of BHI (Harris et al., 1989); the occasional production of hydrogen peroxide was destroyed by the addition of catalase (Corsetti et al., 1996; Moreno et al., 1999). After incubation, each plate received an overlay of 8 $\mathrm{mL}$ of semisolid BHI (with agar 0.8\%) containing approximately $10^{5} \mathrm{cfu} / \mathrm{mL}$ of the $L$. monocytogenes culture (sensitive microorganism). After solidification, the plates were incubated at $35^{\circ} \mathrm{C}$ for $24 \mathrm{~h}$ and were examined for the formation of an inhibition halo around the inoculated culture, indicating antagonistic activity by the tested culture. An aliquot of $2 \mu \mathrm{L}$ of the $L b$. sakei 2a culture was also plated onto all plates as positive control of antagonistic LAB because of its bacteriocinogenic nature (de Martinis and Franco, 1998). The cultures identified as antagonistic were then further characterized according to morphology (Gram stain) and the production of catalase.

Enzymatic Sensitivity of Antimicrobial Substances. After obtaining the results of the antagonism test, all cultures with antimicrobial activity were submitted to additional assays to confirm the proteinaceous nature of the antagonistic substances according to the methodology described by Lewus et al. (1991), with the following modifications. Colonies isolated from the antagonistic cultures were grown in MRS broth and incubated at $25^{\circ} \mathrm{C}$ for $24 \mathrm{~h}$. Aliquots of $2 \mu \mathrm{L}$ of each culture were plated in at least 5 replications onto plates containing $10 \mathrm{~mL}$ of modified MRS agar (containing dextrose $0.5 \%$ ) and were incubated at $25^{\circ} \mathrm{C}$ for $24 \mathrm{~h}$ under anaerobiosis (Anaerobac, Probac do Brasil). After incubation, a well (2 $\mathrm{mm}$ diameter) was made in the agar at a distance of $0.5 \mathrm{~cm}$ from each formed colony, and each well was filled with $20 \mu \mathrm{L}$ of a solution $(20 \mathrm{mg} / \mathrm{mL})$ of the following enzymes (Sigma): $\alpha$-chymotrypsin (from bovine pancreas), proteinase $\mathrm{K}$ (from Tritirachium album), and trypsin (from bovine pancreas). In addition, $20 \mu \mathrm{L}$ of sterile distilled water was added in 1 of the wells as a negative control. After $30 \mathrm{~min}$ at room temperature (absorption and diffusion), each plate received an overlay of $8 \mathrm{~mL}$ of semisolid BHI agar $(0.8 \%)$ containing approximately $10^{5} \mathrm{cfu} / \mathrm{mL}$ of the L. monocytogenes culture (sensitive microorganism) and was incubated at $35^{\circ} \mathrm{C}$ for $24 \mathrm{~h}$. The production of bacteriocin-like substances by the cultures was confirmed by sensitivity to 1 or more enzymes tested, as identified by the formation of a half moon-shaped halo.

\section{Bacteriocinogenic LAB Molecular Analyses}

$\boldsymbol{P C R}$. Considering the obtained results for morphological characterization and antagonistic activity, 20 LAB cultures were selected for molecular identification and detection of genes related to bacteriocin production.

Initial molecular studies were performed to identify the LAB group through the conserved region of the $16 \mathrm{~S}$ rRNA gene (Kullen et al., 2000). For these assays, 1 colony of each culture was recovered in MRS broth (at $35^{\circ} \mathrm{C}$ for $24 \mathrm{~h}$ ). After incubation, $1 \mathrm{~mL}$ of the culture was microcentrifuged for $5 \mathrm{~min}$ at $6,000 \times \mathrm{g}$. The supernatant was removed and the pellet was processed for DNA extraction according to Pospiech and Neumann (1995). For PCR, the Illustra PureTaq Ready-to-go 
PCR beads kit (GE Healthcare, Chalfont St. Giles, UK) was used, and the oligonucleotides in the assay were plb16 (5' AGAGTTTGATCCTGGCTCAG $3^{\prime}$ ) and mlb16 ( $5^{\prime}$ GGCTGCTGGCACGTAGTTAG $3^{\prime}$ ), as described by Kullen et al. (2000). The PCR products resulted in a fragment of $500 \mathrm{bp}$ from the conserved region of the $16 \mathrm{~S}$ rRNA gene. The thermocycler was programmed for 5 min at $94^{\circ} \mathrm{C}, 35$ cycles of $15 \mathrm{~s}$ at $94^{\circ} \mathrm{C}, 15 \mathrm{~s}$ at $55^{\circ} \mathrm{C}$, and $1 \mathrm{~min}$ at $72^{\circ} \mathrm{C}$, and $10 \mathrm{~min}$ at $72^{\circ} \mathrm{C}$. The products of the reactions were submitted to gel electrophoresis in a $1.0 \%$ (wt/vol) agarose gel stained with ethidium bromide and visualized under UV illumination (Kullen et al., 2000).

Sequencing and Sequence Analyses of Nucleotides. After PCR products were purified with the Wizard SV Gel kit and PCR Clean-Up System (Promega Corp., Madison, WI), they underwent automatic sequencing using the methodology adapted from Sanger et al. (1977), performed by Macrogen Inc. (Seoul, South Korea). The obtained nucleotide sequences were compared with sequences previously deposited in the GenBank using the Basic Alignment Search Tool (BLAST) software system (http://www.ncbi.nlm.nih.gov). Next, the sequences were grouped by the neighbor-joining method (with the Poisson correction) according to their genetic profiles using the MEGA 4.0 software system (Tamura et al., 2007). Association analyses were performed using the 1000 bootstrap method. The partial sequence of the 16S rRNA gene from Lactobacillus acidophilus ATCC 4356 (access number: M58802) was used in the construction of the external grouping of the phylogenetic tree.

Nisin Genes Detection. The cultures identified as Lc. lactis ssp. lactis were analyzed to detect the presence of genes encoding nisin. The DNA of the cultures was extracted using the Wizard Genomic DNA Purification kit (Promega). The sequences of oligonucleotides employed (nisAf1: 5' AAAATGAGTACAAAAGATTTYAAC 3'; nisBr3: $5^{\prime}$ TGCATAACATCATAGAGTTTAGG $3^{\prime}$; nisAf2: $5^{\prime}$ TTCACGTAAGCAAATAACCA $3^{\prime}$; and nisAr2: $5^{\prime}$ TGGTTATTTGCTTACGTGAA $3^{\prime}$ ) and the amplification cycles of the PCR were according to Espeche et al. (2009). Oligonucleotides were combined as follows: nisAf1/nisAr2 (product $\sim 160 \mathrm{bp}$ ), nisAf2/ nisBr3 (product $\sim 270 \mathrm{bp}$ ), and nisAf1/nisBr3 (product $\sim 430 \mathrm{bp}$ ). The Illustra PureTaq Ready-to-go PCR beads kit (GE Healthcare) was then used, with the thermocycler programmed for 4 min at $94^{\circ} \mathrm{C}, 30$ cycles of $30 \mathrm{~s}$ at $94^{\circ} \mathrm{C}, 30 \mathrm{~s}$ at $49^{\circ} \mathrm{C}$, and $45 \mathrm{~s}$ at $72^{\circ} \mathrm{C}$, and 5 min at $72^{\circ} \mathrm{C}$. The products of the reactions were submitted to electrophoresis in a $1.0 \%$ (wt/vol) agarose gel and were visualized using ethidium bromide under UV illumination (Espeche et al., 2009). The strain Lc. lactis ssp. lactis DY 13 was used as a positive control.
Table 1. Frequencies of autochthonous cultures isolated from raw milk and soft cheese that demonstrated antimicrobial activity against Listeria monocytogenes ATCC 7644

\begin{tabular}{lc}
\hline $\begin{array}{l}\text { Inhibition halo size } \\
\text { (radius, mm) }\end{array}$ & $\begin{array}{c}\text { Target microorganism } \\
(\text { L. monocytogenes })\end{array}$ \\
\hline Absence & 339 \\
$<5$ & 8 \\
5 to 10 & 32 \\
10 to 15 & 18 \\
$>15$ & 0 \\
Total & 389 \\
\hline
\end{tabular}

\section{RESULTS}

\section{Antagonistic Activity of Naturally Occurring LAB}

Antagonistic activity was evaluated according to the production of bacteriocin-like substances by the selected cultures. Of these, $58(14.9 \%)$ cultures presented antagonistic activity against L. monocytogenes (Table 1). According to the genuine characteristics of LAB (de Martinis et al., 2003), all antagonistic cultures presented negative results for the catalase test and were classified as gram-positive, with cocci as the prevailing morphology (55 cultures, 94.8\%). The observed results were similar to those obtained by Franciosi et al. (2009).

\section{Enzymatic Sensitivity of Antimicrobial Substances}

Lactic acid bacteria cultures with antimicrobial activity were submitted to additional tests to confirm the proteinaceous nature of the antagonistic substances and, consequently, their bacteriocinogenic-like nature. Most cultures produced extracts that presented sensitivity to 1 or more enzymes, confirming their ability to produce bacteriocin-like substances (Table 2). The methodology used did not allow for the identification of sensitivity to enzymes in 14 cultures because of the formation of a very small inhibition halo during the analyses. Some antimicrobial activity loss may have occurred in these cultures, as suggested by Hoover and Steenson (1993).

\section{Bacteriocinogenic LAB Molecular Analyses}

Although it is impossible to detect sensitivity to proteases in some extracts, 20 cultures were selected, submitted to PCR based on the conserved region of the 16S rRNA gene, and subsequently underwent genetic sequencing (Table 3), confirming the previous identification of the cultures as LAB. Only 2 species, Lc. lactis ssp. lactis and Lactobacillus plantarum, were identified and divided into different strains. A high variability of these strains was observed in the samples of cheese, whereas raw milk samples presented only 1 strain, $L c$. lactis ssp. lactis (Table 3). The phylogenetic analysis of 
Table 2. Enzymatic sensitivity patterns of the antimicrobial substances produced by cultures of lactic acid bacteria isolated from raw milk and soft cheese

\begin{tabular}{|c|c|c|c|}
\hline \multicolumn{3}{|c|}{ Enzyme } & \multirow[b]{2}{*}{$\mathrm{n}$} \\
\hline Proteinase $\mathrm{K}$ & Trypsin & $\alpha$-Chymotrypsin & \\
\hline Sensitive & Sensitive & Sensitive & 18 \\
\hline Sensitive & Not sensitive & Sensitive & 11 \\
\hline Sensitive & Not sensitive & Not sensitive & 5 \\
\hline Not sensitive & Sensitive & Sensitive & 4 \\
\hline Not sensitive & Sensitive & Not sensitive & 3 \\
\hline Not sensitive & Not sensitive & Sensitive & 2 \\
\hline Sensitive & Sensitive & Not sensitive & 1 \\
\hline Not sensitive & Not sensitive & Not sensitive & 14 \\
\hline
\end{tabular}

the isolates identified the presence of different groupings of cultures with similar genetic characteristics, although they were identified as different strains of $L c$. lactis ssp. lactis and Lb. plantarum.

\section{DISCUSSION}

It was observed that $58(14.9 \%)$ LAB cultures produced antagonistic strains against L. monocytogenes, with 18 presenting inhibition halos greater than $10 \mathrm{~mm}$ in radius (Table 1). In a similar study, Coventry et al. (1997) isolated several cultures from milk and cheese that were able to produce bacteriocins with antimicrobial activity against L. monocytogenes; these were also identified as nisin and pediocin producers. In addition, several studies have demonstrated the antagonistic activity of autochthonous cultures isolated from dairy and meat products against L. monocytogenes (Winkowski et al., 1993; Rodríguez et al., 2000; Nero et al., 2009b), indicating the potential use of these cultures in the control of this pathogen, as observed in the present study (Table 1).
The variation in sensitivity of bacteriocins and bacteriocin-like substances to different enzymes is important for the identification of potential uses of these cultures in the control of foodborne pathogens (Table 2). Similar types of enzyme sensitivities of bacteriocinogenic LAB have been observed in other studies (Tükel et al., 2007; Rashid et al., 2009).

The identified strains (Table 3) were often described as bacteriocin or bacteriocin-like substance producers (Chen and Hoover, 2003), suggesting their possible applicability as biopreservatives in the food industry. In addition, these cultures are typically present in dairy products (Rodríguez et al., 2000; Dolci et al., 2008). Lactobacillus plantarum is able to produce different kinds of plantaricins, which are bacteriocins that present antimicrobial activity against several microorganisms such as LAB, Staphylococcus aureus, Bacillus cereus, Clostridium sporogenes, and some species of the Enterobacteriaceae family (Chen and Hoover, 2003; Hernández et al., 2005). Lactococcus lactis ssp. lactis is able to produce several bacteriocins including nisin, the best characterized and only bacteriocin considered safe for consumption (GRAS, generally regarded as safe) (Chen and Hoover, 2003; Cotter et al., 2005). Nisin is used as a preservative by the food industry (Cotter et al., 2005) and presents a broad spectrum of activity against different gram-positive microorganisms (Chen and Hoover, 2003).

Molecular methodologies are extremely important in studies of antagonism because they allow for the precise identification of LAB isolates (Mohania et al., 2008), genes known as codifiers of already described bacteriocins, and new sequences of genes that codify new antimicrobial metabolites (Nes and Johnsborg, 2004). From the 18 cultures identified as Lc. lactis ssp. lactis, 7 tested positive for nisin genes by PCR (Figure 1). Nisin

Table 3. Identification of bacteriocinogenic or bacteriocinogenic-like lactic acid bacteria cultures isolated from raw milk and soft cheese, as well as genetic information obtained by sequencing of the $16 \mathrm{~S}$ rRNA gene

\begin{tabular}{|c|c|c|c|c|c|}
\hline Origin & No. of identified cultures & Species & Strain & Identity $^{1}$ & GenBank no. \\
\hline \multirow{3}{*}{ Raw milk } & 1 & Lactococcus lactis ssp. lactis & RO37 & $471 / 485$ & AF515226.1 \\
\hline & 1 & Lactococcus lactis ssp. lactis & 0711XYBLS & $480 / 484$ & EU869288.1 \\
\hline & & Lactococcus lactis & SL3 & $480 / 484$ & AY675242.1 \\
\hline \multirow[t]{6}{*}{ Soft cheese } & 7 & Lactococcus lactis ssp. lactis & RO37 & $482 / 485$ & AF515226.1 \\
\hline & 1 & Lactobacillus plantarum & WCFS1 & $498 / 505$ & AL935261.1 \\
\hline & 1 & Lactobacillus plantarum & L5 & $496 / 501$ & DQ239698.1 \\
\hline & & Lactobacillus plantarum & L2 & $496 / 501$ & DQ239695.1 \\
\hline & & Lactobacillus plantarum & LP3 & $496 / 501$ & AY675256.1 \\
\hline & & Lactobacillus plantarum & WCFS1 & $496 / 501$ & AL935261.1 \\
\hline
\end{tabular}

${ }^{1}$ Identity $=$ number of identical bases/total number of analyzed bases. 
is not degraded by trypsin, $\alpha$-chymotrypsin, catalase, or pepsin (Cholett et al., 2008), and the obtained results (Figure 2) indicated that only culture 32M3 expressed nisin genes and produced this bacteriocin. Based on the results of the enzymatic tests, the other isolates with positive results for nisin (31M7, 17M2, 48M5, 54M2, $22 \mathrm{M} 8$, and $19 \mathrm{M} 3$ ) did not demonstrate the production of either this substance or other bacteriocins (Figure 2).

The results of the phylogenetic analysis by genetic sequencing, together with the enzymatic profile of the bacteriocins and bacteriocin-like substances and the positive genetic variations for nisin codification, allow for the observation of wide variability among the isolates (Figure 2). The 11 cultures of Lc. lactis ssp. lactis that belonged to the largest phylogenetic grouping presented relevant differences in the enzymatic sensitivity of the bacteriocins and bacteriocin-like substances and also carried genes for nisin.

The obtained results indicate a great amount of variability among the bacteriocin or bacteriocin-like substances produced by LAB isolates that were identified

nisAf1 - nisAr2
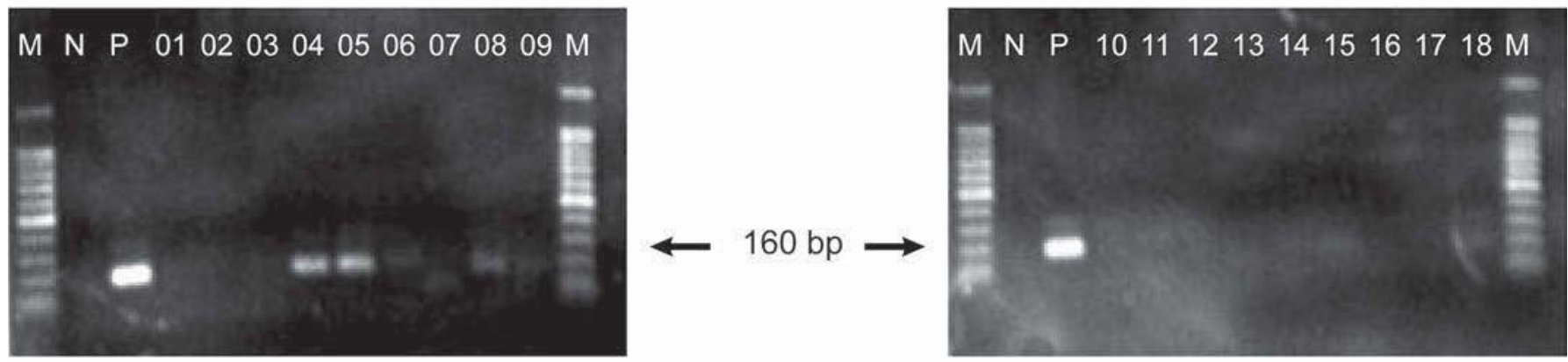

nisAf2 - nisBr3
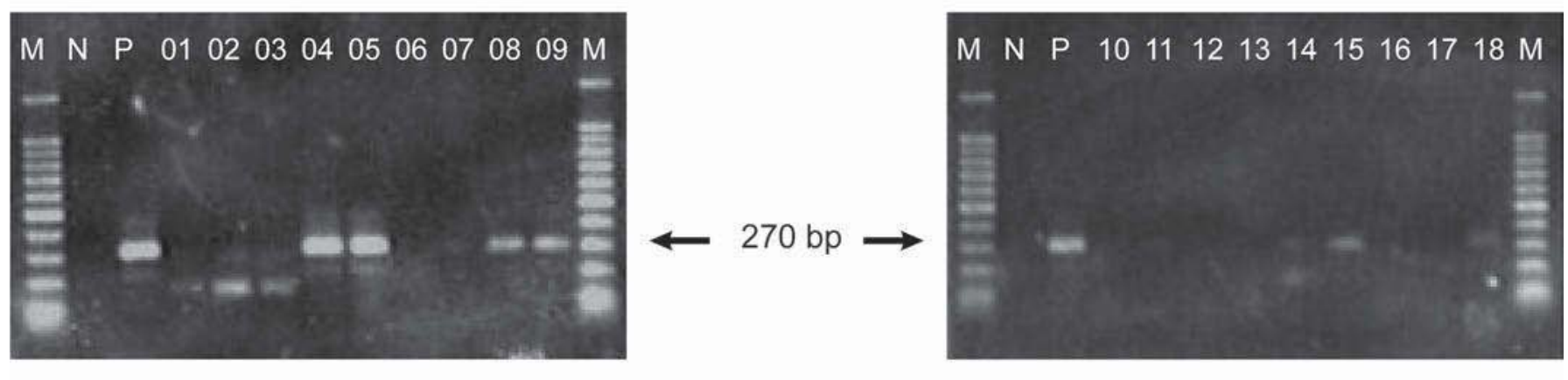

nisAf1 - nisBr3

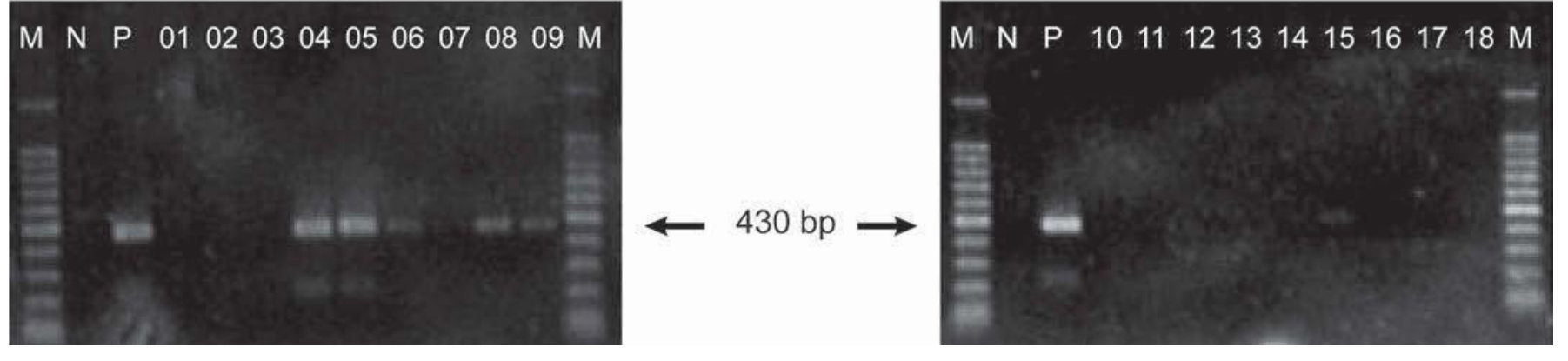

Figure 1. Molecular identification of nisin coding genes by PCR: nisAf1-nisAr2 (product $\sim 160$ bp), nisAf2-nisBr3 (product $~ 270$ bp), and nisAf1-nisBr3 (product $\sim 430 \mathrm{bp}$ ). $\mathrm{M}=100$-bp ladder; $\mathrm{N}=$ negative control; $\mathrm{P}=$ positive control; 01 to $18=$ tested cultures. 


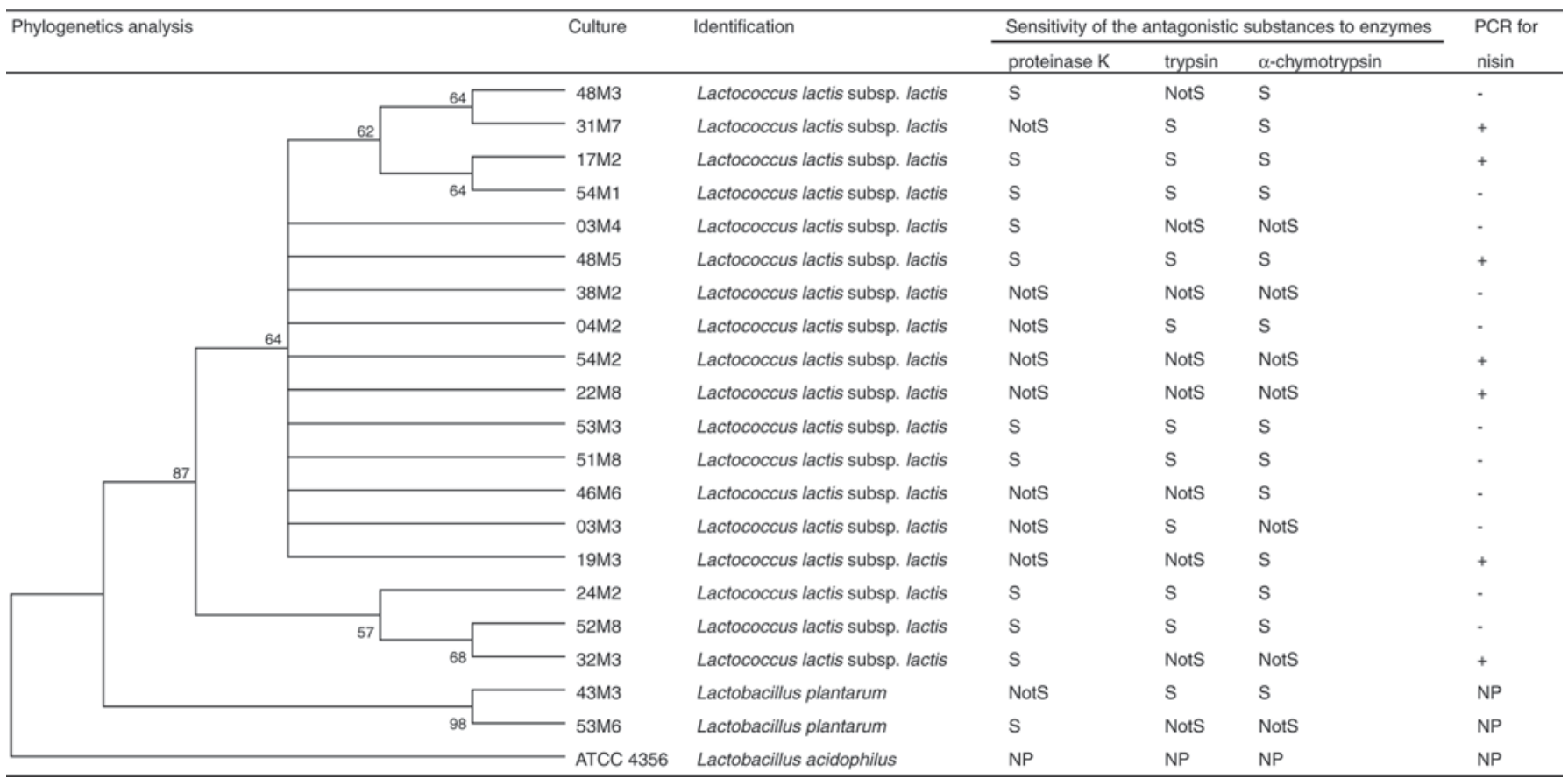

Figure 2. Genetic grouping based on the partial sequence of nucleotides of the Lactobacillus acidophilus ATCC 4356, identification by genetic sequencing, sensitivity to enzymes, and presence of genes related to the encoding of nisin from cultures of bacteriocinogenic or bacteriocinogeniclike lactic acid bacteria isolated from raw milk and soft cheese. The length of the horizontal bar of the groups is proportional to the genetic distance between the isolates. The numbers next to the lines indicate the percentage of repetitions of the bootstrap analysis in which ramifications were observed. $\mathrm{S}=$ sensitive to the enzyme solution; NotS = not sensitive to the enzyme solution; $\mathrm{NP}=$ test not performed; $+=$ positive; $-=$ negative.

as antagonistic against L. monocytogenes. These characteristics suggest that these cultures could potentially be used as biopreservatives in dairy products and diverse processing situations. Further studies are necessary for a better understanding of the antimicrobial potential of these cultures.

\section{ACKNOWLEDGMENTS}

This work was supported by CNPq (Conselho Nacional de Desenvolvimento Científico e Tecnológico; Masters scholarship and 474044/2006-8) and FAPEMIG (Fundação de Amparo à Pesquisa do Estado de Minas Gerais; CVZ 301/06 and CVZ APQ-2602-5.05/07). The authors are also thankful to Elaine de Martinis (Universidade de São Paulo, Faculdade de Ciências Farmacêuticas, Ribeirão Preto, São Paulo).

\section{REFERENCES}

Carr, F. J., D. Chill, and N. Maida. 2002. The lactic acid bacteria: A literature survey. Crit. Rev. Microbiol. 28:281-370.

Chen, H., and D. G. Hoover. 2003. Bacteriocins and their food applications. Compr. Rev. Food Sci. 2:82-100.

Cholett, E., I. Sebti, A. Martial-Gros, and P. Degraeve. 2008. Nisin preliminary study as a potential preservative for sliced ripened cheese: $\mathrm{NaCl}$, fat and enzymes influence on nisin concentration and its antimicrobial activity. Food Contr. 19:982-989.
Corsetti, A., M. Gobbetti, and E. Smacchi. 1996. Antibacterial activity of sourdough lactic acid bacteria: Isolation of a bacteriocin-like inhibitory substance from Lactobacillus sanfrancisco C57. Food Microbiol. 13:447-456.

Cotter, P. D., C. Hill, and P. R. Ross. 2005. Bacteriocins: Developing innate immunity for food. Nat. Rev. Microbiol. 3:777-788.

Coventry, M. J., J. B. Gordon, A. Wilcock, K. Harmark, B. E. Davidson, M. W. Hickey, A. J. Hillier, and J. Wan. 1997. Detection of bacteriocins of lactic acid bacteria isolated from foods and comparison with pediocin and nisin. J. Appl. Microbiol. 83:248258.

de Martinis, E. C. P., and B. D. G. M. Franco. 1998. Inhibition of Listeria monocytogenes in a pork product by a Lactobacillus sake strain. Int. J. Food Microbiol. 42:119-126.

de Martinis, E. C. P., and F. Z. Freitas. 2003. Screening of lactic acid bacteria from Brazilian meats for bacteriocin production. Food Contr. 14:197-200.

de Martinis, E. C. P., P. R. Santarosa, and F. Z. Freitas. 2003. Caracterização preliminar de bacteriocinas produzidas por seis cepas de bactérias láticas isoladas de produtos cárneos embalados à vácuo. Ciên. Tecnol. Alim. 23:195-199.

Dolci, P., V. Alessandria, G. Zeppa, K. Rantsiou, and L. Cocolin. 2008. Microbiological characterization of artisanal Raschera PDO cheese: Analysis of its indigenous lactic acid bacteria. Food Microbiol. 25:392-399.

Espeche, M. C., M. C. Otero, F. Sesma, and M. E. F. Nader-Macias. 2009. Screening of surface properties and antagonistic substances production by lactic acid bacteria isolated from mammary gland of healthy and mastitic cows. Vet. Microbiol. 135:346-357.

Franciosi, E., L. Settanni, A. Cavazza, and E. Poznanski. 2009. Biodiversity and technological potential of wild lactic acid bacteria from raw cows' milk. Int. Dairy J. 19:3-11.

Harris, L. J., M. A. Daeschel, M. E. Stiles, and T. R. Klaenhammer. 1989. Antimicrobial activity of lactic acid bacteria against Listeria monocytogenes. J. Food Prot. 52:384-387. 
Hernández, D., E. Cardell, and V. Zárate. 2005. Antimicrobial activity of lactic acid bacteria isolated from Tenerife cheese: Initial characterization of plantaricin TF711, a bacteriocin-like substance produced by Lactobacillus plantarum TF711. J. Appl. Microbiol. 99:77-84.

Holzapfel, W. H., P. Haberer, R. Geisen, J. Björkroth, and U. Schillinger. 2001. Taxonomy and important features of probiotic microorganisms in food and nutrition. Am. J. Clin. Nutr. $73: 365 \mathrm{~S}-373 \mathrm{~S}$

Hoover, D. G., and L. R. Steenson. 1993. Bacteriocins of Lactic Acid Bacteria. Academic Press, New York, NY.

Issa, M. S., and E. T. Ryser. 2000. Fate of Listeria monocytogenes, Salmonella Typhimurium DT104, and Escherichia coli O157:H7 in Labneh as a pre and postfermentation contaminant. J. Food Prot. 63:608-612.

Kullen, M. J., R. B. Sanozky-Dawes, D. C. Crowell, and T. R. Klaenhammer. 2000. Use of DNA sequence of variable regions of the $16 \mathrm{~S}$ rRNA gene for rapid and accurate identification of bacteria in the Lactobacillus acidophilus complex. J. Appl. Microbiol. 89:511-516.

Lewus, C. B., A. Kaiser, and T. J. Montville. 1991. Inhibition of foodborne bacterial pathogens by bacteriocins from lactic acid bacteria isolated from meat. Appl. Environ. Microbiol. 57:1683-1688.

Lewus, C. B., and T. J. Montville. 1991. Detection of bacteriocins produced by lactic acid bacteria. J. Microbiol. Methods 13:145150

Maldonado, A., J. L. Ruiz-Barba, and R. Jiménez-Díaz. 2003 Purification and genetic characterization of plantaricin NC8, a novel coculture-inducible two-peptide bacteriocin from Lactobacillus plantarum NC8. Appl. Environ. Microbiol. 69:383-389.

Mohania, D., R. Nagpal, M. Kumar, A. Bhardwaj, M. Yadav, S. Jain, F. Marotta, V. Sing, O. Parkash, and H. Yadav. 2008. Molecular approaches for identification and characterization of lactic acid bacteria. J. Dig. Dis. 9:190-198.

Moreno, I., A. L. S. Lerayer, and M. F. F. Leitão. 1999. Detection and characterization of bacteriocin-producing Lactococcus lactis strains. Rev. Microbiol. 30:130-136.

Nero, L. A., M. R. Mattos, V. Beloti, M. A. F. Barros, M. B. T. Ortolani, and B. D. G. M. Franco. 2009b. Autochthonous microbiota of raw milk with antagonistic activity against Listeria monocytogenes and Salmonella Enteridis. J. Food Saf. 29:261-270.

Nero, L. A., G. N. Viçosa, and F. E. Pereira. 2009a. Qualidade microbiológica do leite determinada por características de produção. Cien. Tecnol. Alim. 29:386-390.

Nes, I. F., and O. Johnsborg. 2004. Exploration of antimicrobial potential in LAB by genomics. Curr. Opin. Biotechnol. 15:100104.

Pospiech, A., and B. Neumann. 1995. A versatile quick-prep of genomic DNA from gram-positive bacteria. Trends Genet. 11:217-218.

Rashid, M. H., K. Togo, M. Ueda, and T. Miyamoto. 2009 Characterization of bacteriocin produced by Streptococcus bovis J2 40-2 isolated from traditional fermented milk 'Dahi'. Anim. Sci. J. 80:70-78.

Rodríguez, E., B. González, P. Gaya, M. Nuñez, and M. Medina. 2000. Diversity of bacteriocins produced by lactic acid bacteria isolated from raw milk. Int. Dairy J. 10:7-15.

Sanger, F., S. Nicklen, and A. R. Coulson. 1977. DNA sequencing with chain-terminating inhibitors. Proc. Natl. Acad. Sci. USA $74: 5463-5467$

Tamura, K., J. Dudley, M. Nei, and S. Kumar. 2007. MEGA4: Molecular Evolutionary Genetics Analysis (MEGA) software version 4.0. Mol. Biol. Evol. 24:1596-1599.

Thuault, D., E. Beliard, J. Le Guerin, and C. M. Bourgeois. 1991 Inhibition of Clostridium tyrobutyricum by bacteriocin-like substances produced by lactic acid bacteria. J. Dairy Sci. $74: 1145-1150$.

Todokoro, D., H. Tomita, T. Inoue, and Y. Ike. 2006. Genetic analysis of bacteriocin 43 of vancomycin-resistant Enterococcus faecium. Appl. Environ. Microbiol. 72:6955-6964.

Tükel, C., M. D. Avşaroğlu, Ö. Şımșek, and M. Akçelık. 2007. Isolation and partial characterization of a novel bacteriocin produced by Lactococcus lactis ssp. lactis MC38. J. Food Saf. 27:17-29.

Winkowski, K., A. D. Crandall, and T. J. Montville. 1993. Inhibition of Listeria monocytogenes by Lactobacillus bavaricus MN in beef systems at refrigeration temperatures. Appl. Environ. Microbiol. 59:2552-2557. 